Open Access

\title{
Prognostic role of hormone receptors in endometrial cancer: a systematic review and meta-analysis
}

Yanli Zhang ${ }^{1 \dagger}$, Dong Zhao ${ }^{1 \dagger}$, Changguo Gong ${ }^{3 \dagger}$, Fengmei Zhang ${ }^{3}$, Jing $\mathrm{He}^{3}$, Wei Zhang ${ }^{3}$, Yulan Zhao ${ }^{2^{*}}$ and Jing Sun ${ }^{1 *}$

\begin{abstract}
Background: The aim of this study was to summarize the global predicting role of hormone receptors for survival in endometrial cancer.

Methods: Eligible studies were identified and assessed for quality through multiple search strategies. Data were collected from studies comparing overall survival (OS), cancer-specific survival (CSS), or progression-free survival (PFS) in patients with elevated levels of estrogen receptor (ER), progesterone receptor (PR), or human epidermal growth factor receptor 2 (HER2) with those in patients with lower levels. The combined hazard ratios of ER, PR, and HER2 for survival were calculated.

Results: A total of 98 studies were included for meta-analysis (44 for ER, 38 for PR, and 16 for HER2). Higher levels of either ER or PR could significantly indicate better survival. The pooled hazard ratios (HRs) of ER for OS, CSS, and PFS were $0.75(95 \% \mathrm{Cl}, 0.68-0.83), 0.45(95 \% \mathrm{Cl}, 0.33-0.62)$, and 0.66 (95\% Cl, 0.52-0.85), respectively. The combined HRs of PR for OS, CSS, and PFS reached $0.63(95 \% \mathrm{Cl}, 0.56-0.71), 0.62(95 \% \mathrm{Cl}$, $0.42-0.93)$, and 0.45 (95\% Cl, 0.30-0.68), respectively. In contrast, elevated levels of HER2 could predict worse outcome with a HR of $1.98(95 \% \mathrm{Cl}, 1.49-2.62)$ for OS, and a HR of 2.26 (95\% Cl, 1.57-3.25) for PFS.

Conclusions: In patients with endometrial cancer, higher level of ER and PR predicted favorable survival, and increased level of HER2 was associated with poorer survival. All of the three hormone receptors had prognostic value for survival.
\end{abstract}

Keywords: Endometrial cancer, Estrogen receptor, Progesterone receptor, Human epidermal growth factor receptor 2, Prognosis

\section{Background}

Endometrial cancer (EC) is the fourth most common malignancy in women and the most common gynecologic cancer [1], and in 2014, 52,630 new cases was diagnosed with an estimated 8590 deaths predicted in the USA alone [2]. The incidence of EC is also increasing in developing countries in the past decades [3, 4]. Overall,

\footnotetext{
*Correspondence: ylzhao@imet.ecnu.edu.cn; sunjing61867@126.com

${ }^{\dagger}$ Equal contributors

${ }^{2}$ School of Life Science, East China Normal University, North Zhongshan Road \#3663, Shanghai, People's Republic of China

'Department of Minimally Invasive Gynecologic Surgery, Shanghai First Maternity and Infant Hospital, Tongji University School of Medicine, Changle Road \#536, Shanghai 200040, People's Republic of China

Full list of author information is available at the end of the article
}

the 5-year survival rates for EC are approximately 78-90 \% for stage I, $74 \%$ for stage II, 36-57 \% for stage III, and $20 \%$ for stage IV [5]. Additionally, women with metastatic disease have only a median survival of 7-12 months [6]. Such poor outcomes raise an urgent requirement that more accurate prognosis and predictive markers should be applied for EC to guide the therapy and monitor the disease progress for individual patients.

Endometrial cancer is the most common genital tract malignancy in women and consists of two major histological types, endometrioid endometrial cancer, and non-endometrioid endometrial cancer including highrisk malignancies such as serous papillary and clear cell carcinoma. Endometrioid endometrial carcinoma is the

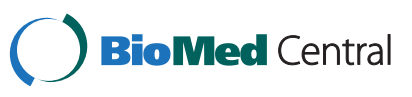


most common form, accountable for more than 75-90 \% of all cases of endometrial cancer [7].

Besides conventional clinical or pathological features, some biological molecules have been proposed as prognostic biomarkers in EC, such as P53, KRAS, PTEN, EGFR, FGFR, estrogen receptors (ER), progesterone receptors (PR), human epidermal growth factor receptor 2 (HER2), and so on [8]. Among them, hormone receptors are attractive because of their physiological functions. Through binding to their receptors, estrogen drives epithelial proliferation, and progesterone inhibits growth and causes cell differentiation. Interestingly, women who ovulate and produce progesterone almost never get endometrial cancer. Oppositely, disruption of the functions of hormone receptors can lead to several types of malignancies [9]. Due to higher response rates reported for hormone receptor-positive tumors, these receptors are currently considered to be important therapeutic targets and markers for the choice of treatment [10]. HER2 is a member of the human epidermal growth factor receptor tyrosine kinase family, which regulates many processes that can promote tumor cell proliferation and survival [11]. HER2 pathway, which may interact with $E R$, is one of the most important pathways that have been implicated in the development of endocrine resistance in breast cancer. With the development of molecular biology and immunologic method, all of the three hormone receptors have been introduced to refine outcome prediction of female cancers, such as breast cancer, ovarian cancer, and endometrial cancer.

Our previous meta-analysis reported that higher level of PR predicted favorable survival, and elevated level of HER2 was associated with worse survival in ovarian cancer. Furthermore, ER- $\beta$ may be a potentially strong predictor for better outcome [12]. A comparable situation may also exist in research of $\mathrm{EC}$, another malignant tumor affected by the interaction between steroid hormones and their respective receptors. Although a pile of clinical studies on prognostic value of ER, PR, and HER2 expression levels in EC has also been done, no clear conclusion could be drawn to date. In 1985, Creasman et al. reported that hormone receptor expression correlates with disease-free survival in stages I and II endometrial carcinoma [13]. However, inconsistent results were obtained in the followed studies [14-17]. For example, some studies showed that elevated levels of ER or PR could significantly predict favorable outcome [18, 19], whereas some other studies showed insignificant results [20-22]. Moreover, some studies suggested that elevated HER2 level was associated with poorer survival, whereas other studies could not draw such significant conclusion $[20,22]$.

Therefore, it is timely and necessary to analyze globally the prognostic value of hormone receptors in a larger population. In this study, we seek to conduct a metaanalysis to evaluate the overall risk of hormone receptors for endometrial cancer survival. We discussed endometrial carcinoma and uterine papillary serous carcinoma in this text.

\section{Methods}

We performed meta-analysis following the guidelines of the Meta-analysis of Observational Studies in Epidemiology group (MOOSE) [23].

\section{Search strategy}

We carefully searched online PubMed and EMBASE from 1979 to May 2014 to identify relevant studies. Three distinct sets of key words were used simultaneously in each set, namely, "estrogen receptor and endometrial cancer prognosis," "progesterone receptor and endometrial cancer prognosis," and "human epidermal growth factor receptor 2 and endometrial cancer prognosis." Studies were considered eligible if they met the following criteria: (1) they measured preoperative ER, PR, or HER2 values; (2) they evaluated the potential association between preoperative ER, PR, or HER2 levels and the outcome of endometrial cancer; (3) their study was retrospective or prospective in design; and (4) the median period of follow-up was no shorter than 6 months. Articles were excluded based on the following criteria: (1) review articles or letters, (2) non-English articles, (3) laboratory studies, and (4) absence of key information such as sample size, hazards ratio (HR), $95 \%$ confidence interval (CI), and $P$ value.

Titles, abstracts, full texts, and reference lists of all of the identified reports were examined independently by three reviewers (Zhang Y, Gong C, and Zhang F). These extracted data have been double-checked by each other. Disagreements were resolved by consensus between the three readers or consultation with a fourth reviewer (Zhao Y or Zhao D). In addition, a manual search was conducted using references from the relevant literature, including all of the identified studies, reviews, and editorials. We e-mailed to the authors of studies for additional information and the data needed for the meta-analytic calculations. When duplicate studies were retrieved, we included in our systematic review the study having reported HRs or involving more patients (usually the latest). This was performed to avoid overlapping between cohorts and overestimation of the overall HR.

\section{Quality assessment}

According to a critical review checklist of the Dutch Cochrane Centre proposed by MOOSE, we systematically assessed the quality of all the studies included [23]. The key points of the current checklist include (1) clear definition of study population; (2) clear definition of 
study design; (3) clear definition of outcome assessment, such as overall survival (OS), cancer-specific survival (CSS), disease-specific survival (DSS), progression-free survival (PFS), disease-free survival (DFS), or recurrencefree survival (RFS); and (4) sufficient period of follow-up. If a study does not mention all four points, it was excluded so as not to compromise the quality of the meta-analysis. A flow diagram of the study selection process is presented in Fig. 1.

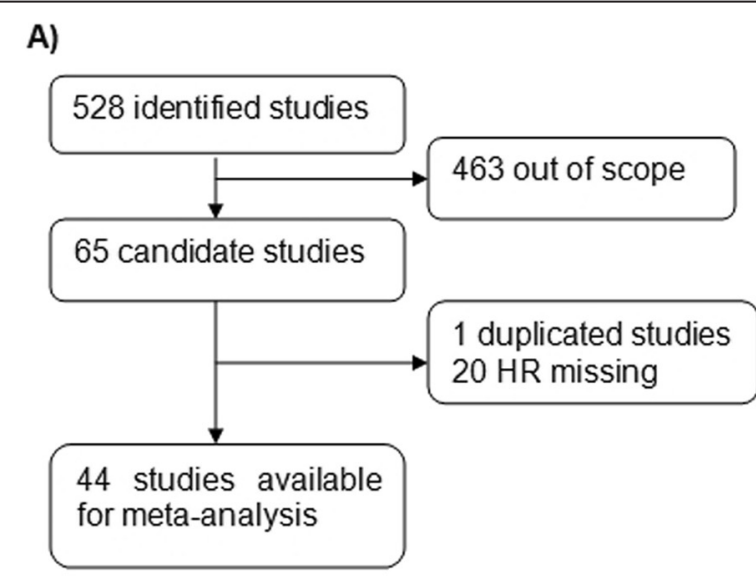

B)

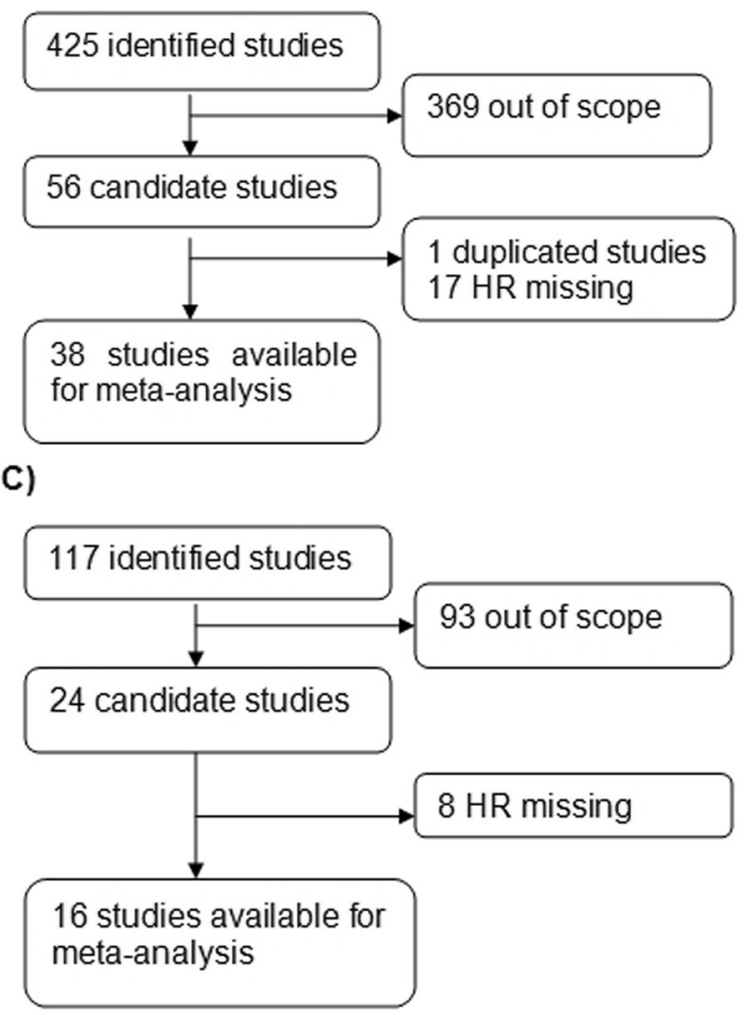

Fig. 1 Flow diagram of the study selection process. a ER studies. b PR studies. c HER2 studies

\section{Data extraction and conversion}

The extracted data elements of this review included (1) publication details: first author's last name, publication year, and origin of the studied population; (2) study design; (3) characteristics of the studied population: sample size, age, stage of disease, or histological type; and (4) HR of elevated ER, PR, and HER2 for OS, CSS (including DSS), and PFS (including DFS and RFS), as well as their $95 \% \mathrm{CI}$ and $P$ value. The simplest method consisted in the direct collection of HR, odds ratio or risk ratio, and their $95 \% \mathrm{CI}$ from the original article, with an HR of less than 1 being associated with a better outcome. If not available, the total numbers of observed deaths/cancer recurrences and the numbers of patients in each group were extracted to calculate HR .When data were only available as Kaplan-Meier curves, data were extracted from the graphical survival plots, and estimation of the HR was then performed using the described method.

\section{Statistical analysis}

A test of heterogeneity of combined HRs was conducted using Cochran $Q$ test and Higgins I-squared statistic. A $P$ value of less than 0.05 was considered significant. A random-effect model (Der Simonian and Laird method) was used if heterogeneity was observed $(P<0.05)$, whereas the fixed-effect model was applied in the absence of between-study heterogeneity $(P<0.05)$. Publication bias was evaluated using the funnel plot with the Egger bias indicator test [24]. All analyses were conducted using Stata: Data Analysis and Statistical Software V10.1 (http://www.stata.com/).

\section{Results and discussion}

A total of 528 records for ER were identified from a primary literature search in PubMed and EMBASE. After manually screening the titles, abstracts, and key data, 463 studies were excluded because they were review articles, letters, non-English articles, laboratory studies, studies with important data missing, or studies irrelevant to the current analysis. Of the 65 reports selected for detailed evaluation, 1 study was excluded for being duplicated; 20 others were excluded for lack of key data, such as HR. The final meta-analysis was carried out for the remaining 44 studies $(n=7119)$ for ER $[13,14,16-18$, 20-22, 25-61] (Fig. 1a). A similar identification process was carried out in 425 studies for PR and 117 studies for HER2. Finally, 38 studies recruiting 5502 patients for PR $[13,14,16-18,20-22,25,26,29,31,32,34-43,50-59$, 61-65] (Fig. 1b) and 16 studies recruiting 1764 patients for HER2 were included [20, 22, 33, 52, 54, 66-76] (Fig. 1c). The main features of eligible studies are summarized in Table 1. We collected data from Australia, China, England, Finland, Germany, Greece, Italy, Japan, 
Table 1 Summary table of the meta-analysis

\begin{tabular}{|c|c|c|c|c|c|c|c|c|}
\hline \multicolumn{9}{|l|}{ A) ER } \\
\hline & Country & $\begin{array}{l}\text { Study } \\
\text { design }\end{array}$ & Disease & $N$ & Age (range) & $\begin{array}{l}\text { Survival } \\
\text { analysis }\end{array}$ & $\begin{array}{l}\text { Hazard } \\
\text { ratios }\end{array}$ & Follow-up, months \\
\hline $\begin{array}{l}\text { Athanassiadou } \\
1999 \text { [39] }\end{array}$ & Greece & $\mathrm{R}$ & EC & 80 & $62.7(48-82)$ & OS & SC & 140 \\
\hline Backe 1997 [54] & German & $\mathrm{R}$ & EC & 124 & $68(30-94)$ & OS & Reported & $57.6(0.24-180)$ \\
\hline Borazjani 1989 [40] & USA & $\mathrm{R}$ & EC & 44 & $66(36-86)$ & OS & SC & 120 \\
\hline $\begin{array}{l}\text { Chambers } \\
1988-1[51]\end{array}$ & USA & $\mathrm{R}$ & EC & 168 & - & OS & $\mathrm{DE}$ & $24(1-118.8)$ \\
\hline Covens 2011 [45] & USA & $P$ & EC & 67 & - & OS, PFS & SC & 36 \\
\hline Creasman 1985 [13] & USA & $\mathrm{R}$ & EC & 168 & $63(30-92)$ & DFS & $\mathrm{DE}$ & $25(1-74)$ \\
\hline Engelsen 2008 [34] & Norway & $\mathrm{R}$ & EC & 230 & - & OS & SC & 192 \\
\hline Felix 2012 [28] & USA & $\mathrm{R}$ & EC & 199 & - & OS, RFS & SC & $42(0.8-144)$ \\
\hline Fukuda 1998 [14] & Japan & $\mathrm{R}$ & EEC & 92 & $60.3(31-86)$ & DFS, OS & SC, reported & $61.2(0-174)$ \\
\hline Gates 2006 [52] & USA & $\mathrm{R}$ & EC & 108 & $64.2(27-95)$ & OS & $\mathrm{DE}$ & 60 \\
\hline $\begin{array}{l}\text { Gonzalez-Rodilla } \\
2013 \text { [20] }\end{array}$ & Spain & $\mathrm{R}$ & EC & 126 & $65.9(43-88)$ & OS & Report & 70 \\
\hline Gul 2010 [31] & Turkey & $\mathrm{R}$ & EC & 49 & $58.3(30-81)$ & OS & $\mathrm{DE}$ & 24 \\
\hline Huvila 2013 [61] & Finland & $\mathrm{R}$ & EEC & 182 & $67(35-93)$ & DFS & Reported & $62.8(4.2-84.4)$ \\
\hline Ito 2005 [57] & Japan & $\mathrm{R}$ & EEC & 103 & 57 & OS & Reported & $60(2-148)$ \\
\hline Jongen 2009 [17] & Netherlands & $\mathrm{R}$ & EEC & 315 & $64.7(32-89)$ & $\begin{array}{l}\text { DSS, RFS, } \\
\text { OS }\end{array}$ & SC & $59.6(0-258)$ \\
\hline Kadar 1993 [16] & USA & $\mathrm{R}$ & EC & 137 & - & OS & $\mathrm{DE}$ & 60 \\
\hline Kamat 2009 [32] & USA & $\mathrm{R}$ & EEC & 139 & $63(27-91)$ & DSS & Reported & 24.9 \\
\hline $\begin{array}{l}\text { Kalogiannidis } \\
2008[35]\end{array}$ & Greece & $\mathrm{R}$ & EC & 77 & $62.5(35-80)$ & OS, CSS, DFS & $\mathrm{DE}$ & $60(9-120)$ \\
\hline Kauppila 1986 [42] & Finland & $\mathrm{R}$ & EC & 153 & - & DFS, OS & SC & $42(12-96)$ \\
\hline $\begin{array}{l}\text { Krakstad } \\
\text { 2012-primary [27] }\end{array}$ & Norway & $P$ & EC & 182 & - & DSS & SC & 60 \\
\hline $\begin{array}{l}\text { Krakstad } \\
\text { 2012-prospective [27] }\end{array}$ & Norway & $P$ & EC & 474 & - & DSS & SC & 60 \\
\hline Lenhard 2013 [59] & German & $P$ & EC & 292 & 65.1 (35.6-88) & OS & Reported & $13.8(13.1-14.5)$ \\
\hline Liao 1986 [43] & USA & $\mathrm{R}$ & EC & 75 & - & OS & SC & 50 \\
\hline Lindahl 1992 [50] & Sweden & $\mathrm{R}$ & EC & 298 & $63(36-87)$ & OS & $\mathrm{DE}$ & 60 \\
\hline Martin 1983 [44] & Australia & $P$ & EC & 87 & $(48-85)$ & OS & SC & $(8-68)$ \\
\hline Merritt 2010 [55] & USA & $\mathrm{R}$ & EEC & 85 & $63.4(39-91)$ & DSS & Reported & 72 \\
\hline $\begin{array}{l}\text { Mhawech-Fauceglia } \\
2013 \text { [48] }\end{array}$ & USA & $\mathrm{R}$ & EC & 316 & - & OS & $\mathrm{DE}$ & 60 \\
\hline Mylonas 2010 [30] & Germany & R & EEC & 214 & $65.1(35-88)$ & PFS, CSS, OS & SC & $96.3(0.03-176.8)$ \\
\hline Palmer 1988 [41] & Australia & $\mathrm{R}$ & EC & 351 & $64.5(31-89)$ & OS & SC & 100 \\
\hline Pertschuk 1996 [47] & $\begin{array}{l}\text { Caucasian, } \\
\text { Hispanic, } \\
\text { Oriental }\end{array}$ & $\mathrm{R}$ & EC & 78 & $65.5(38-89)$ & OS & SC & $37.5(13-161)$ \\
\hline Pradhan 2012 [26] & Norwegian & $P$ & UPSC & 52 & $72(56-89)$ & OS, PFS & $\mathrm{DE}$ & 60 \\
\hline Saito 2006 [56] & Japan & $\mathrm{R}$ & EEC & 103 & 57 & DFS, OS & Reported & $60(2-148)$ \\
\hline Rahman 2013 [18] & Japan & $\mathrm{R}$ & $\mathrm{EEC}$ & 111 & $60(26-85)$ & PFS, OS & Reported & $52(5-139)$ \\
\hline Salvesen 1998 [58] & Norway & $P$ & EC & 97 & 65 (37-92) & OS & DE & $108(60-180)$ \\
\hline Shabani 2007 [36] & Germany & $\mathrm{R}$ & EC & 293 & 64.8 (35.5-88) & PFS, CSS, OS & SC & $89.6(3.2-135.5)$ \\
\hline Sho 2014 [60] & Japan & $\mathrm{R}$ & UPSC & 33 & $69.6(55-82)$ & CSS & Reported & $29(2-174)$ \\
\hline
\end{tabular}


Table 1 Summary table of the meta-analysis (Continued)

\begin{tabular}{|c|c|c|c|c|c|c|c|c|}
\hline Singh 2007 [37] & USA & $P$ & EC & 48 & - & OS & Reported & 19 \\
\hline Sivridis 2001 [38] & Greece & $\mathrm{R}$ & EC & 164 & - & OS & SC & $55(19-167)$ \\
\hline Song 2012 [29] & Korea & $\mathrm{R}$ & EC & 137 & $53.7(30-82)$ & OS & Reported & 60 \\
\hline Sun 2013 [46] & China & $P$ & EC & 73 & $58(30-78)$ & DFS & SC & $43.4(16-91)$ \\
\hline Voss 2011 [22] & England & $P$ & EC & 156 & $68.2(37-89)$ & DSS, RFS & Reported & $48.1(0.1-141.5)$ \\
\hline Wik 2013-R [49] & Norway & $\mathrm{R}$ & EC & 266 & - & DSS & SC & 300 \\
\hline Wik 2013-P [49] & Norway & $P$ & EC & 153 & - & DSS & SC & 300 \\
\hline Zannoni 2013 [25] & Italy & $P$ & EEA & 121 & $59(35-88)$ & DFS, OS & Reported & $38(14-91)$ \\
\hline Zhang 2013 [53] & China & $\mathrm{R}$ & EC & 239 & $54(26-82)$ & DFS, OS & $\mathrm{DE}$ & $67(12-183)$ \\
\hline Zou 2012 [21] & China & $\mathrm{R}$ & $\mathrm{EEC}$ & 60 & $51.3(30-72)$ & OS & Reported & $45.5(3-69.5)$ \\
\hline \multicolumn{9}{|l|}{ B) $P R$} \\
\hline & Country & $\begin{array}{l}\text { Study } \\
\text { design }\end{array}$ & Disease & $N$ & Age (range) & $\begin{array}{l}\text { Survival } \\
\text { analysis }\end{array}$ & $\begin{array}{l}\text { Hazard } \\
\text { ratios }\end{array}$ & Follow-up, months \\
\hline $\begin{array}{l}\text { Athanassiadou } \\
1999 \text { [39] }\end{array}$ & Greece & $\mathrm{R}$ & EC & 80 & $62.7(48-82)$ & OS & SC & 140 \\
\hline Backe 1997 [54] & German & $\mathrm{R}$ & EC & 197 & $68(30-94)$ & OS & Reported & $57.6(0.2-180)$ \\
\hline Borazjani 1989 [40] & USA & $\mathrm{R}$ & EC & 44 & $66(36-86)$ & OS & SC & 120 \\
\hline $\begin{array}{l}\text { Chambers } \\
\text { 1988-1 [51] }\end{array}$ & USA & $\mathrm{R}$ & EC & 168 & 67 (49-90) & OS & $\mathrm{DE}$ & $24(1-118.8)$ \\
\hline Creasman 1985 [13] & USA & $\mathrm{R}$ & EC & 105 & $63(30-92)$ & DFS & $\mathrm{DE}$ & $25(1-74)$ \\
\hline Ehrlich 1988 [65] & USA & $\mathrm{R}$ & EC & 174 & $56(25-89)$ & OS & SC & $27(1-152)$ \\
\hline Engelsen 2008 [34] & Norway & $\mathrm{R}$ & EC & 230 & - & OS & Reported & 192 \\
\hline Fukuda 1998 [14] & Japan & $\mathrm{R}$ & $\mathrm{EEC}$ & 92 & $60.3(31-86)$ & DFS & SC & $61.2(0-174)$ \\
\hline Gates 2006 [52] & USA & $\mathrm{R}$ & EC & 108 & $64.2(27-95)$ & OS & Report & 60 \\
\hline $\begin{array}{l}\text { Gonzalez-Rodilla } \\
2013 \text { [20] }\end{array}$ & Spain & $\mathrm{R}$ & EC & 126 & $65.9(43-88)$ & OS & Reported & 70 \\
\hline Gul 2010 [31] & Turkey & $\mathrm{R}$ & EC & 49 & $58.3(30-81)$ & OS & $\mathrm{DE}$ & 24 \\
\hline Huvila 2013 [61] & Finland & $\mathrm{R}$ & EEC & 182 & 67 (35-93) & DFS & Reported & $62.8(4.2-84.4)$ \\
\hline Ito 2005 [57] & Japan & $\mathrm{R}$ & $\mathrm{EEC}$ & 103 & 57 & DFS, OS & Reported & $60(2-148)$ \\
\hline Jongen 2009 [17] & Netherlands & $\mathrm{R}$ & $\mathrm{EEC}$ & 300 & $64.7(32.0-89.0)$ & DSS, RFS, OS & SC, reported & $59.6(0-258)$ \\
\hline Kadar 1993 [16] & USA & $\mathrm{R}$ & EC & 137 & - & OS & $\mathrm{DE}$ & 60 \\
\hline $\begin{array}{l}\text { Kalogiannidis } \\
2008 \text { [35] }\end{array}$ & Greece & $\mathrm{R}$ & EC & 77 & $62.5(35-80)$ & OS, CSS, DFS & $\mathrm{DE}$ & $60(9-120)$ \\
\hline Kamat 2009 [32] & USA & $\mathrm{R}$ & EEC & 139 & $63(27-91)$ & DSS & report & 24.9 \\
\hline Kauppila 1986 [42] & Finland & $\mathrm{R}$ & EC & 153 & - & DFS, OS & SC & $42(12-96)$ \\
\hline Liao 1986 [43] & USA & $\mathrm{R}$ & EC & 86 & & OS & SC & 50 \\
\hline Lenhard 2013 [59] & German & $P$ & EC & 292 & $65.1(35.6-88.1)$ & OS & Reported & $13.8(13.1-14.5)$ \\
\hline Lindahl 1992 [50] & Sweden & $\mathrm{R}$ & EC & 272 & $63(36-87)$ & OS & $\mathrm{DE}$ & 60 \\
\hline Merritt 2010 [55] & USA & $\mathrm{R}$ & $\mathrm{EEC}$ & 85 & $63.4(39-91)$ & DSS & Reported & 72 \\
\hline Palmer 1988 [41] & Australia & $\mathrm{R}$ & EC & 351 & $64.5(31-89)$ & OS & SC & 100 \\
\hline Pradhan 2012 [26] & Norwegian & $P$ & SAC & 50 & $72(56-89)$ & OS, PFS & $\mathrm{DE}$ & 60 \\
\hline Rahman 2013 [18] & Japanese & $\mathrm{R}$ & EEC & 110 & $60(26-85)$ & PFS, OS & Reported & $52(5-139)$ \\
\hline Sakaguchi 2004 [62] & Japan & $\mathrm{R}$ & EC & 120 & $32-74$ & OS & SC & 60 \\
\hline Saito 2006 [56] & Japan & $P$ & $\mathrm{EEC}$ & 103 & 57 & DFS, OS & Reported & $60(2-148)$ \\
\hline Salvesen 1998 [58] & Norway & $P$ & EC & 96 & 65 (37-92) & OS & Reported & $108(60-180)$ \\
\hline Shabani 2007 [36] & Germany & $\mathrm{R}$ & EC & 293 & $64.8(35.5-87.9)$ & PFS, CSS, OS & SC & $89.6(3.2-135.5)$ \\
\hline Singh 2007 [37] & USA & $P$ & EC & 49 & & OS & Reported & 19 \\
\hline
\end{tabular}


Table 1 Summary table of the meta-analysis (Continued)

\begin{tabular}{|c|c|c|c|c|c|c|c|c|}
\hline Sivridis 2001 [38] & Greece & $\mathrm{R}$ & $\mathrm{EC}$ & 164 & - & OS & SC & $55(19-167)$ \\
\hline Song 2012 [29] & Korea & $\mathrm{R}$ & EC & 137 & $53.7(30-82)$ & OS & Reported & 60 \\
\hline Steiner 2003 [63] & Germany & $\mathrm{R}$ & EC & 115 & $65(38-81)$ & OS, RFS & SC & $72(36-156)$ \\
\hline Sutton 1989 [64] & USA & $\mathrm{R}$ & EC & 139 & $61(31-89)$ & DFS & $S C, D E$ & $28.9(1-128)$ \\
\hline Voss 2011 [22] & England & $P$ & EC & 156 & $68.2(37-89)$ & DSS, RFS & Reported & $48.1(0.1-141.5)$ \\
\hline Zannoni 2013 [25] & Italy & $P$ & EEC & 121 & $59(35-88)$ & DFS, OS & Reported & 38 (14-91) \\
\hline Zhang 2013 [53] & China & $\mathrm{R}$ & EC & 239 & $54(26-82)$ & $\begin{array}{l}\text { DFS, OS, } \\
\text { RFS }\end{array}$ & SC & $67(12-183)$ \\
\hline Zou 2012 [21] & China & $\mathrm{R}$ & $\mathrm{EEC}$ & 60 & $51.3(30-72)$ & OS & Reported & $45.5(3-69.5)$ \\
\hline \multicolumn{9}{|l|}{ C) HER2 } \\
\hline & Country & $\begin{array}{l}\text { Study } \\
\text { design }\end{array}$ & Disease & $N$ & Age (range) & $\begin{array}{l}\text { Survival } \\
\text { analysis }\end{array}$ & $\begin{array}{l}\text { Hazard } \\
\text { ratios }\end{array}$ & Follow-up, months \\
\hline Backe 1997 [54] & German & $\mathrm{R}$ & EC & 222 & $68(30-94)$ & OS, RFS & SC & $57.6(0.24-180)$ \\
\hline Cianciulli 2003 [76] & Italy & $\mathrm{R}$ & EC & 73 & & OS & SC & 72 \\
\hline Coronado 2001 [72] & Spain & $\mathrm{R}$ & $\mathrm{EC}$ & 114 & $65(37-85)$ & PFS & SC & $6(14-107)$ \\
\hline Gates 2006 [52] & USA & $\mathrm{R}$ & EC & 99 & $64.2(27-95)$ & OS & report & 60 \\
\hline $\begin{array}{l}\text { Gonzalez-Rodilla } \\
2013 \text { [20] }\end{array}$ & Spain & $\mathrm{R}$ & EC & 126 & $65.9(43-88)$ & OS & report & 70 \\
\hline Jongen 2009-2 [33] & Netherlands & $P$ & $\mathrm{EEC}$ & 315 & $64.7(32-89)$ & OS, RFS & Reported & $59.6(0-258)$ \\
\hline Kohlberger 1996 [73] & Australia & $\mathrm{R}$ & EC & 100 & $64(36-85)$ & OS & SC & 140 \\
\hline Konecny 2009 [68] & USA & $\mathrm{R}$ & EC & 273 & $65(38-90)$ & OS & SC & $\begin{array}{l}\text { EEA83 }(0.3-270) \\
\text { USPC20 }(0.1-162) \text {, } \\
\text { CCC38 }(0.2-180)\end{array}$ \\
\hline Mori 2010 [67] & Japan & $\mathrm{R}$ & $\mathrm{EEC}$ & 63 & $57.5(32-78)$ & RFS, OS & SC & $61.9(7-133)$ \\
\hline Odicino 2008 [69] & Italy & $\mathrm{R}$ & USPC & 10 & $\begin{array}{l}\text { positive: } 79-84 ; \\
\text { negative: } 57-76\end{array}$ & OS & $\mathrm{DE}$ & $19.7(1-87)$ \\
\hline Peiro 2004 [76] & German & $\mathrm{R}$ & EC & 10 & 60 (29-91) & OS & SC, reported & 53 \\
\hline Saffari 1995 [74] & Hispanic & $\mathrm{R}$ & EC & 75 & $60(29-87)$ & OS & SC & 144 \\
\hline Santin 2005-1 [70] & USA & $\mathrm{R}$ & USPC & 27 & $66(62-75)$ & DSS, OS & SC, reported & $33(10-48)$ \\
\hline Santin 2005-2 [71] & USA & $\mathrm{R}$ & USPC & 30 & $67.5(63-75)$ & OS & SC & $42(10-51)$ \\
\hline Togami 2012 [66] & Japan & $\mathrm{R}$ & UPSC & 71 & $63.6(47-81)$ & RFS, OS & Reported & $49.7(4-125)$ \\
\hline Voss 2011 [22] & England & $P$ & EC & 156 & $68.2(37-89)$ & DSS, RFS & Reported & $48.12(0.12-141.48)$ \\
\hline
\end{tabular}

Study design is described as prospective $(\mathrm{P})$ or retrospective $(\mathrm{R})$

EC endometrial cancer, EEC endometrioid endometrial cancer, UPSC uterine papillary serous carcinoma, OS overall survival, CSS cancer-specific survival, DSS disease-specific survival, PFS progression-free survival, RFS relapse-free survival, DFS disease-free survival, DE data-extrapolated, SC survival curve

-not reported

[ ] Reference number

Korea, Netherlands, Norway, Spain, Sweden, Turkey, and the USA.

A test of heterogeneity of combined HRs was conducted using Cochran $Q$ test and Higgins I-squared statistic. A $P$ value of less than 0.05 was considered significant. A random-effect model (Der Simonian and Laird method) was used if heterogeneity was observed $(P<0.05)$, whereas the fixed-effect model was applied in the absence of between-study heterogeneity $(P<0.05)$. Publication bias was evaluated using the funnel plot with the Egger bias indicator test. For studies assessing EC, there mostly appeared to have heterogeneity between studies for ER, PR, and HER2 $(P<0.05)$. Hence, a random model was applied to calculate a pooled HR and its $95 \%$ CI. Higher levels of either ER or PR could significantly indicate better survival. The pooled HRs of ER for OS, CSS, and PFS were 0.75 (95\% CI, 0.68-0.83), 0.45 (95\% CI, 0.33-0.62), and 0.66 (95\% CI, 0.52-0.85), respectively (Fig. 2a-c). The combined HRs of PR for OS, CSS, and PFS reached 0.63 (95\% CI, 0.56-0.71), 0.62 (95\% CI, 0.42-0.93), and 0.45 (95\% CI, 0.30-0.68), respectively (Fig. 2d-f). In contrast, elevated levels of HER2 could predict worse outcome with a HR of 1.98 (95\% CI, 1.49-2.62) for OS, and a HR of 2.26 (95 \% CI, 1.57-3.25) for PFS (Fig. 2g, h). Such results indicated that in patients with EC, higher level of ER and PR predicted favorable survival, and 


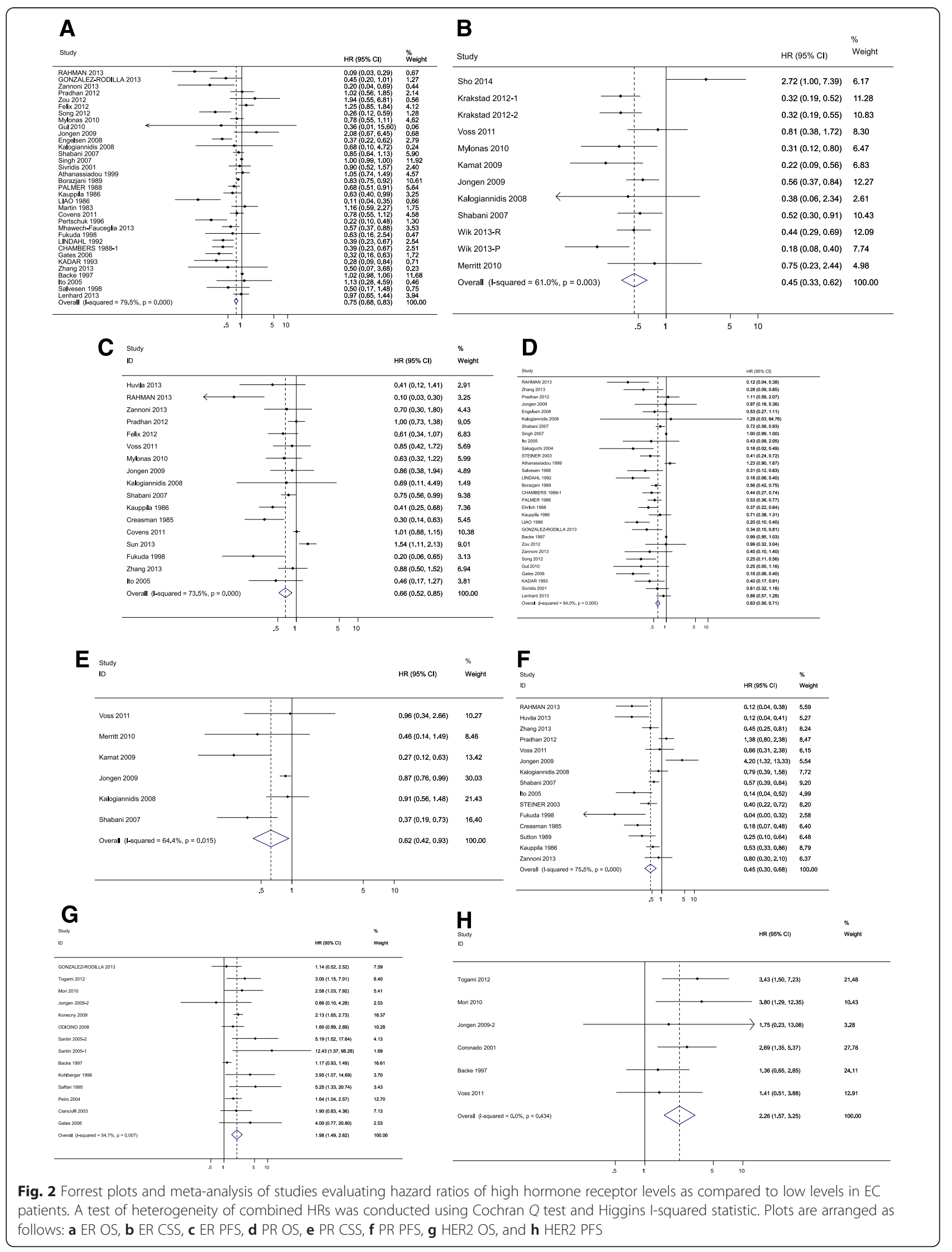


increased level of HER2 was associated with poorer survival. All of the three hormone receptors had prognostic value for survival. Then, publication bias of the ERs and PRs studies were evaluated by funnel plots and Egger tests as shown in Table 2 .

Previous studies reported that two distinct receptors(ER- $\alpha$ and ER- $\beta$ ) may exert opposite effects on cellular processes that include proliferation, apoptosis, and migration, and their different effects may depend on tumor type and disease stage [77]. Considering that the different subtypes of ER and PR may have

Table 2 Comparison of the predicting value of ER-a, ER- $\beta$, PR-A, and PR-B in EC patients

\begin{tabular}{|c|c|c|c|c|}
\hline & & OS & CSS & PFS \\
\hline \multirow[t]{7}{*}{ ER-a } & $\mathrm{HR}$ & $0.73(0.52-1.03)$ & $0.54(0.30-0.98)$ & $0.84(0.57-1.24)$ \\
\hline & $\begin{array}{l}\text { Heterogeneity, } \\
P \text { value }\end{array}$ & 0.013 & 0.001 & 0.013 \\
\hline & Model & Fixed & Random & Fixed \\
\hline & Bias, $P$ value & 0.379 & 0.968 & 0.975 \\
\hline & $N$ & 1568 & 1332 & 1119 \\
\hline & Study & 7 & 5 & 6 \\
\hline & $\mathrm{HR}$ & $0.90(0.45-1.80)$ & - & $0.84(0.49-1.44)$ \\
\hline \multirow[t]{6}{*}{ ER- $\beta$} & $\begin{array}{l}\text { Heterogeneity, } \\
P \text { value }\end{array}$ & 0.847 & - & 0.805 \\
\hline & Model & Fixed & - & Fixed \\
\hline & Bias, $P$ value & 0.771 & - & 0.287 \\
\hline & $N$ & 925 & - & 925 \\
\hline & Study & 4 & - & 4 \\
\hline & $\mathrm{HR}$ & $1.00(0.99-1.00)$ & - & $0.78(0.18-3.44)$ \\
\hline \multirow[t]{6}{*}{ PR-A } & $\begin{array}{l}\text { Heterogeneity, } \\
P \text { value }\end{array}$ & 0.066 & - & 0.001 \\
\hline & Model & Fixed & - & Fixed \\
\hline & Bias, $P$ value & 0.026 & - & 0.652 \\
\hline & $N$ & 1038 & - & 696 \\
\hline & Study & 5 & - & 3 \\
\hline & $\mathrm{HR}$ & $0.67(0.49-0.90)$ & - & $0.60(0.43-0.82)$ \\
\hline \multirow[t]{5}{*}{ PR-B } & $\begin{array}{l}\text { Heterogeneity, } \\
P \text { value }\end{array}$ & 0.841 & - & 0.656 \\
\hline & Model & Random & - & Random \\
\hline & Bias, $P$ value & 0.748 & - & 0.32 \\
\hline & $N$ & 696 & - & 696 \\
\hline & Study & 3 & - & 3 \\
\hline
\end{tabular}

A test of heterogeneity of combined HRs was conducted using Cochran $Q$ test and Higgins I-squared statistic. A random-effect model (Der Simonian and Laird method) was used if heterogeneity was observed $(P<0.05)$, whereas the fixed-effect model was applied in the absence of between-study heterogeneity $(P<0.05)$. Publication bias was evaluated using the funnel plot with the Egger bias indicator test

$E C$ endometrial cancer, $E R$ - $a$ estrogen receptor-alpha, $E R-\beta$ estrogen receptorbeta, $P R-A$ progesterone receptor-A, $P R-B$ progesterone receptor- $B, H R$ hazards ratio, OS overall survival, CSS cancer-specific survival, DSS disease-specific survival, PFS progression-free survival, DFS disease-free survival, RFS relapse-free survival different effects on cancer survival, we identified that the studies focusing on ER- $\alpha$, ER- $\beta$, PR-A, and PR-B performed a meta-analysis. The pooled HRs of ER- $\alpha$ for OS, CSS, and PFS were 0.73 (95\% CI, 0.52-1.03), 0.54 (95\% CI, 0.30-0.98), 0.84 (95\% CI, 0.57-1.24), respectively. The combined HRs of ER- $\beta$ for OS and PFS were 0.90 (95\% CI, $0.45-1.80$ ) and 0.84 (95\% CI, 0.49-1.44). The pooled HRs of PR-A for OS and PFS were 1.00 (95 \% CI, 0.99-1.00) and 0.78 (95\% CI, 0.18-3.44). The combined HRs of PR-B for OS and PFS were 0.67 (95\% CI, 0.49-0.90) and 0.60 (95\% CI, 0.43-0.82). The results are summarized in Table 2.

The pathogenetic role and prognostic value of HER2 in EC, especially in uterine papillary serous carcinomas [78], one of the most malignant histological types of EC, have recently become the focus of several studies, providing the molecular basis for targeted immunotherapy against the highly aggressive tumors [66, 69, 79-84]. Then we tried to identify the studies focusing on uterine papillary serous carcinoma (UPSC) and performed a meta-analysis. Although there were only four studies $(n=138)$ that could be included in this subgroup meta-analysis, the pooled HR was 2.41 with $95 \%$ CI from 1.54 to $3.76(P<0.05)$ for OS $[66,69-71]$ (Fig. 3). The HR was significant, and it was potentially strong as a HR of an empirical cutoff for strong predictor [84].

\section{Conclusions}

This meta-analysis indicated that hormone receptors may have value in predicting survival in patients with endometrial cancer. The higher levels of ER and PR were significantly associated with favorable survival, whereas the increased level of HER2 predicted poorer survival. All of the three hormone receptors had prognostic value for survival. ER and PR expression are used to identify endometrial cancer (EC) patients that could benefit of hormone therapy, and there are many evidences suggesting that they can be good biomarkers predicting hormone therapy response, but further validation will be required before they are incorporated in routine management of EC patients.

However, this meta-analysis has several limitations and the conclusions should be tempered. First, marked heterogeneity of subjects existed in distinct groups. The heterogeneity of the population was probably due to the difference in the baseline characteristics of patients (age, tumor stage, race, methodology for assessing HRs expression, or country), the cutoff value of markers, the undergoing treatment, the duration of follow-up, and others. To minimize the residual confounding effect caused by the heterogeneity within these studies, a random-effect model was applied. Furthermore, publication 


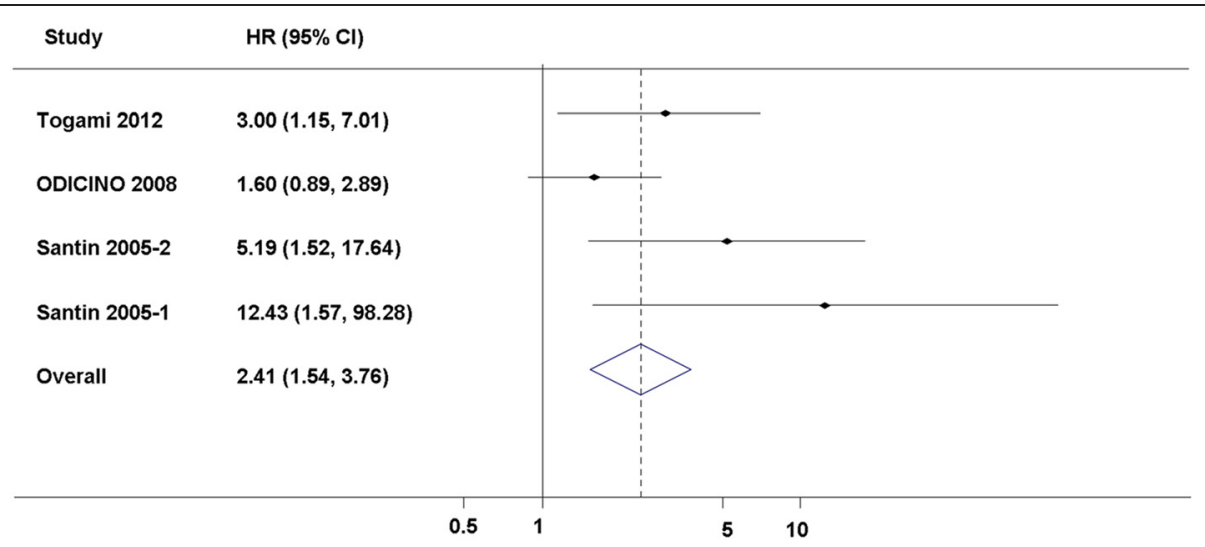

Fig. 3 Forrest plots and meta-analysis of studies evaluating hazard ratios of HER2 levels as compared to low levels about OS in UPSC patients. A test of heterogeneity of combined HRs was conducted using Cochran $Q$ test and Higgins I-squared statistic

bias was detected in all the meta-analyses, and this cannot be adequately overcome by currently available statistical techniques. In addition, although the result of UPSC subgroup about HER2 was promising, the conclusion should be tempered for the relatively small sample size.

Steroid hormones, including ovarian steroid hormones progesterone and estrogen, play vital roles in the development of benign endometrium and endometrial cancer via their receptors [85]. Estrogens act as a promoter of growth and proliferation of the endometrium via estrogen receptors, while progesterone acts as an estrogen antagonist in endometrial maturation and inhibition of proliferation [86]. The endometrium is very sensitive to sex hormones, and thus a shift in the balance of estrogens and progesterone can cause the development of endometrial cancer [1]. The glandular epithelium from which the cancer arises is hormone responsive, expressing both PRs (PR-A and PR-B) and ERs (ER- $\alpha$ and ER- $\beta$ ) [87].

EC often develops from endometrial hyperplasia, which is attributed to prolonged exposure to estrogen in the absence of (unopposed) sufficient progesterone [88], and is often well differentiated and non-invasive or superficially myoinvasive, rarely producing metastases and expressing ER [89]. Whereas early-stage, well differentiated EC usually retain expression of both receptors, advanced stage, poorly differentiated tumors often lack one or both of these receptors, which has been correlated in many studies with a poor prognosis $[19,47]$. In our meta-analysis, both ER and PR tend to be linked with favorable outcome of endometrial cancer and could be applied as a significant predictor. Our results were consistent with most of the previous basic studies that suggested the protective role of PR in endometrial cancer.

Estrogens stimulate cell proliferation through the classical estrogen receptors ER- $\alpha$ and ER- $\beta$. ER- $\alpha$ and
ER- $\beta$ have a distinct pattern of expression in the tissues [90], which varies during cellular proliferation and differentiation [91]. Usually ER- $\alpha$ was the dominant isoform in specimens of normal and diseased endometrium [92, 93]. Some recent studies revealed that ER- $\alpha$ was associated with aberrant proliferation, inflammation, and the development of malignancy, whereas ER$\beta$ seemed to oppose ER- $\alpha$ actions on cell proliferation by modulating the expression of many ER- $\alpha$-regulated genes and exhibits anti-migratory and anti-invasive properties in cancer cells [77]. In large cohorts of EC patients, ER- $\alpha$ was related to early stage, lower-grade tumors $[17,33]$, whereas ER- $\beta$ was related to late stage EC [94]. Our study also conducted a meta-analysis about different ERs, but elevated ER- $\alpha$ and ER- $\beta$ levels alone had no significant value in predicting favorable survival than non-distinguished ER. Therefore, we suggested more studies on ER- $\alpha$ and ER- $\beta$ in the future to further clarify the distinct role of ERs and PRs in the development of endometrial carcinoma and to also help identify diagnostic or therapeutic markers.

The single-copy PR gene uses separate promoters and translational start sites to produce two isoforms, PR-A and PR-B [95], which are in fact two functionally distinct transcription factors [96] and mediate their own response genes [95, 97-99]. Studies in mice with selective ablation of PR isoforms revealed that PR-A is necessary for ovulation and modulates the anti-proliferative effects of progesterone in the uterus and that PR-B is required for normal mammary gland development and function $[100,101]$. To date, there is no evidence of such selective roles of PR-A and PR-B in human tissues. Clinical data in relation to the prevalence of steroid receptor isoforms PR-A and PR-B are scarce, and the specific mechanism is unclear. In our current meta-analysis, elevated ER- $\alpha$, ER- $\beta$, and PR-A levels did not reach significant level majorly due to the limited study number and sample size. 
The polled HR of PR-B was associated with better outcome, but there were only three studies that could be included in this subgroup meta-analysis. Further analysis in large scale study may contribute to the understanding of ER and PR isoforms expression in EC.

In addition, HER2 plays a crucial role in the growth of both normal tissue and malignant tumors [11]. HER2 amplification and overexpression have been shown to play a key role in the pathogenesis of various different cancer types, including breast, ovarian, gastric, and esophageal carcinomas [102].

HER2 overexpression was also found to be associated with endocrine therapy resistance, and HER2-positive cancer might have a worse clinical outcome [103]. Our study has demonstrated the predictive role of elevated HER2 level for poorer survival. Such data may indicate the harmful role of HER2 in endometrial cancer.

In summary, both elevated level of ER and PR predicted favorable survival, and elevated level of HER2 was associated with worse survival in endometrial cancer. The association between hormone receptor status and survival raises the possibility of different subsets of 3patients with endometrial cancer with different biologic behavior and different response to treatment but similar histology or similar clinical performance. Conventional histological examination alone may not be enough to guide therapy and to refine the outcome prediction. We suggest examining ER, PR, and HER2 levels to evaluate endometrial cancer prognosis.

\footnotetext{
Abbreviations

EC: Endometrial cancer; ER: Estrogen receptor; HER2: Human epidermal growth factor receptor 2; OS: Overall survival; CSS: Cancer-specific survival; DSS: Disease-specific survival; PFS: Progression-free survival; DFS: Disease-free survival; RFS: Relapse-free survival; PR: Progesterone receptor; UPSC: Uterine papillary serous carcinoma.
}

\section{Competing interests}

The authors declare that they have no competing interests.

\section{Authors' contributions}

YZg, DZ, and CG participated in the data research and contributed equally. $J S$ and YZo made central contributions to the conception and design of the meta-analysis and to the analysis and interpretation of data. YZg, DZ, FZ, JH, WZ and YZo were involved in drafting the manuscript. Each author has participated sufficiently in the work to take public responsibility for appropriate portions of the content. All authors gave final approval of the version to be published.

\section{Acknowledgements}

The analysis was supported by National Natural Science Foundation of China (NSFC81471436 and NSFC81402144) and SHDC12013125.

\footnotetext{
Author details

'Department of Minimally Invasive Gynecologic Surgery, Shanghai First Maternity and Infant Hospital, Tongji University School of Medicine, Changle Road \#536, Shanghai 200040, People's Republic of China. ${ }^{2}$ School of Life Science, East China Normal University, North Zhongshan Road \#3663, Shanghai, People's Republic of China. Institutes for Advanced Interdisciplinary Research, East China Normal University, Shanghai, People's Republic of China.
}

Received: 26 December 2014 Accepted: 10 June 2015

Published online: 25 June 2015

\section{References}

1. Yang S, Thiel KW, Leslie KK. Progesterone: the ultimate endometrial tumor suppressor. Trends Endocrinol Metab. 2011;22(4):145-52.

2. Siegel R, Ma J, Zou Z, Jemal A. Cancer statistics, 2014. CA Cancer J Clin. 2014;64(1):9-29.

3. Xiang YB, Zhang W, Gao LF, Liu ZW, Xu WH, Liu EJ, et al. Methods for time trend analysis of cancer incidence rates. Zhonghua Liu Xing Bing Xue Za Zhi. 2004;25(2):173-7.

4. Dan Yang HL-M. Year 1969-2003 study on evolution of endometrial cancer. Fudan Univ. J Med Sci. 2005;32(4):479-83.

5. Lewin SN, Herzog TJ, Barrena Medel NI, Deutsch I, Burke WM, Sun X, et al. Comparative performance of the 2009 international federation of gynecology and obstetrics' staging system for uterine corpus cancer. Obstet Gynecol. 2010;116(5):1141-9.

6. Oza AM, Elit L, Tsao MS, Kamel-Reid S, Biagi J, Provencher DM, et al. Phase II study of temsirolimus in women with recurrent or metastatic endometrial cancer: a trial of the NCIC Clinical Trials Group. J Clin Oncol. 2011;29(24):3278-85.

7. Carlson MJ, Thiel KW, Yang S, Leslie KK. Catch it before it kills: progesterone, obesity, and the prevention of endometrial cancer. Discovery Med. 2012;14(76):215-22.

8. Salvesen HB, Haldorsen IS, Trovik J. Markers for individualised therapy in endometrial carcinoma. Lancet Oncol. 2012;13(8):e353-61.

9. Moore RL, Dai Y, Faller DV. Sirtuin 1 (SIRT1) and steroid hormone receptor activity in cancer. J Endocrinol. 2012;213(1):37-48.

10. Kokka F, Brockbank E, Oram D, Gallagher C, Bryant A. Hormonal therapy in advanced or recurrent endometrial cancer. Cochrane Database Syst Rev. 2010;12:CD007926.

11. Saxena R, Dwivedi A. ErbB family receptor inhibitors as therapeutic agents in breast cancer: current status and future clinical perspective. Med Res Rev. 2012;32(1):166-215.

12. Zhao D, Zhang F, Zhang W, He J, Zhao Y, Sun J. Prognostic role of hormone receptors in ovarian cancer: a systematic review and meta-analysis. Int J Gynecol Cancer. 2013;23(1):25-33.

13. Creasman WT, Soper JT, McCarty Jr KS, McCarty Sr KS, Hinshaw W, Clarke-Pearson DL. Influence of cytoplasmic steroid receptor content on prognosis of early stage endometrial carcinoma. Am J Obstet Gynecol. 1985;151(7):922-32.

14. Fukuda K. Prognostic significance of progesterone receptor immunohistochemistry in endometrial carcinoma. Gynecol Oncol. 1998;69:220-5.

15. Kleine W, Maier T, Geyer H, Pfleiderer A. Estrogen and progesterone receptors in endometrial cancer and their prognostic relevance. Gynecol Oncol. 1990;38(1):59-65.

16. Kadar $\mathrm{N}$, Malfetano $\mathrm{JH}$, Homesley HD. Steroid receptor concentrations in endometrial carcinoma: effect on survival in surgically staged patients. Gynecol Oncol. 1993;50(3):281-6.

17. Jongen $V$, Briet J, de Jong $R$, ten Hoor $K$, Boezen $M$, van der Zee $A$, et al. Expression of estrogen receptor-alpha and -beta and progesterone receptor-A and -B in a large cohort of patients with endometrioid endometrial cancer. Gynecol Oncol. 2009;112(3):537-42.

18. Rahman MT, Nakayama K, Rahman M, Ishikawa M, Katagiri H, Katagiri A, et al. ESR1 gene amplification in endometrial carcinomas: a clinicopathological analysis. Anticancer Res. 2013;33(9):3775-81.

19. Gehrig PA, Van Le L, Olatidoye B, Geradts J. Estrogen receptor status, determined by immunohistochemistry, as a predictor of the recurrence of stage I endometrial carcinoma. Cancer. 1999;86(10):2083-9.

20. Gonzalez-Rodilla I, Aller L, Llorca J, Munoz AB, Verna V, Estevez J, et al. The E-Cadherin expression vs. tumor cell proliferation paradox in endometrial cancer. Anticancer Res. 2013;33(11):5091-5.

21. Zou J, Fan YJ, Meng YQ, Xu H, Fan J. An exploratory analysis of gamma-synuclein expression in endometrioid endometrial cancer. BMJ Open. 2012;2(2):e000611.

22. Voss MA, Gordon N, Maloney S, Ganesan R, Ludeman L, McCarthy K, et al. Tetraspanin CD151 is a novel prognostic marker in poor outcome endometrial cancer. Br J Cancer. 2011;104(10):1611-8. 
23. Stroup DF, Berlin JA, Morton SC, Olkin I, Williamson GD, Rennie D, et al. Meta-analysis of observational studies in epidemiology: a proposal for reporting. Meta-analysis Of Observational Studies in Epidemiology (MOOSE) group. JAMA. 2000;283(15):2008-12.

24. Egger M, Davey Smith G, Schneider M, Minder C. Bias in meta-analysis detected by a simple, graphical test. BMJ. 1997;315(7109):629-34.

25. Zannoni GF, Monterossi G, De Stefano I, Gargini A, Salerno MG, Farulla I, et al. The expression ratios of estrogen receptor a (ERa) to estrogen receptor $\beta 1$ (ERß1) and ERa to ERß2 identify poor clinical outcome in endometrioid endometrial cancer. Hum Pathol. 2013:44(6):1047-54.

26. Pradhan M, Davidson B, Abeler VM, Danielsen HE, Tropé CG, Kristensen GB, et al. DNA ploidy may be a prognostic marker in stage I and II serous adenocarcinoma of the endometrium. Virchows Arch. 2012;461(3):291-8.

27. Krakstad C, Trovik J, Wik E, Engelsen IB, Werner HMJ, Birkeland E, et al. Loss of GPER identifies new targets for therapy among a subgroup of ERa-positive endometrial cancer patients with poor outcome. $\mathrm{Br} J$ Cancer. 2012;106(10):1682-8

28. Felix AS, Stone RA, Chivukula M, Bowser R, Parwani AV, Linkov F, et al. Survival outcomes in endometrial cancer patients are associated with CXCL12 and estrogen receptor expression. Int J Cancer. 2012;131(2):E114-21.

29. Song T, Lee JW, Choi CH, Kim TJ, Bae DS, Sung CO, et al. Ploidy and S-phase fraction are correlated with lymphovascular space invasion that is predictive of outcomes in endometrial cancer. Int J Clin Oncol. 2012;17(6):590-7.

30. Mylonas I. Prognostic significance and clinical importance of estrogen receptor $\alpha$ and $\beta$ in human endometrioid adenocarcinomas. Oncol Rep. 2010:24(2):385-93.

31. Gul A, Keser S, Barisik N, Kandemir N, Cakır C, Sensu S, et al. The relationship of cerb B 2 expression with estrogen receptor and progesterone receptor and prognostic parameters in endometrial carcinomas. Diagn Pathol. 2010;5(1):13.

32. Kamat AA, Coffey D, Merritt WM, Nugent E, Urbauer D, Lin YG, et al. EphA2 overexpression is associated with lack of hormone receptor expression and poor outcome in endometrial cancer. Cancer. 2009;115(12):2684-92.

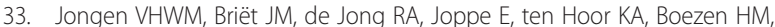
et al. Aromatase, Cyclooxygenase 2, HER-2/neu, and P53 as prognostic factors in endometrioid endometrial cancer. Int J Gynecol Cancer. 2009;19(4):670-6.

34. Engelsen IB, Stefansson IM, Akslen LA, Salvesen HB. GATA3 expression in estrogen receptor a-negative endometrial carcinomas identifies aggressive tumors with high proliferation and poor patient survival. Am J Obstet Gynecol. 2008;199(5):543. e541-7.

35. Kalogiannidis I, Bobos M, Papanikolaou A, Makedos A, Amplianitis I, Vergote I, et al. Immunohistochemical bcl-2 expression, p53 overexpression, PR and ER status in endometrial carcinoma and survival outcomes. Eur J Gynaecol Oncol. 2008:29(1):19-25.

36. Shabani N, Kuhn C, Kunze S, Schulze S, Mayr D, Dian D, et al. Prognostic significance of oestrogen receptor alpha (ERa) and beta (ERB), progesterone receptor $A(P R-A)$ and $B(P R-B)$ in endometrial carcinomas. Eur J Cancer. 2007:43(16):2434-44

37. Singh M, Zaino RJ, Filiaci VJ, Leslie KK. Relationship of estrogen and progesterone receptors to clinical outcome in metastatic endometrial carcinoma: a Gynecologic Oncology Group Study. Gynecol Oncol. 2007:106(2):325-33.

38. Sivridis E, Giatromanolaki A, Koukourakis M, Anastasiadis P. Endometria carcinoma: association of steroid hormone receptor expression with low angiogenesis and bcl-2 expression. Virchows Arch. 2001:438(5):470-7.

39. Athanassiadou P, Petrakakou E, Liossi A, Nakopoulou L, Zerva C, Dimopoulos A, et al. Prognostic significance of p53, bcl-2 and EGFR in carcinoma of the endometrium. Acta Cytol. 1999;43(6):1039-44.

40. Borazjani G. Prognostic significance of steroid receptors measured in primary metastatic and recurrent endometrial carcinoma. Am J Obstet Gynecol. 1989;161:1253-7.

41. Palmer DC, Muir IM, Alexander Al, Cauchi M, Bennett RC, Quinn MA. The prognostic importance of steroid receptors in endometrial carcinoma. Obstet Gynecol. 1988;72(3 Pt 1):388-93.

42. Kauppila AJ, Isotalo HE, Kivinen ST, Vihko RK. Prediction of clinical outcome with estrogen and progestin receptor concentrations and their relationships to clinical and histopathological variables in endometrial cancer. Cancer Res. 1986:46(10):5380-4.
43. Liao BS, Twiggs LB, Leung BS, Yu WC, Potish RA, Prem KA. Cytoplasmic estrogen and progesterone receptors as prognostic parameters in primary endometrial carcinoma. Obstet Gynecol. 1986;67(4):463-7.

44. Martin JD, Hahnel R, McCartney AJ, Woodings TL. The effect of estrogen receptor status on survival in patients with endometrial cancer. Am J Obstet Gynecol. 1983;147(3):322-4.

45. Covens AL, Filiaci V, Gersell D, Lutman CV, Bonebrake A, Lee Y-C. Phase II study of fulvestrant in recurrent/metastatic endometrial carcinoma: a Gynecologic Oncology Group Study. Gynecol Oncol. 2011;120(2):185-8.

46. Sun L, Wang J, Zhang L, Li X, Shen D. Expression of ER-alpha36, a novel variant of estrogen receptor in endometrial carcinoma and its clinical significance. Gynecol Obstet Invest. 2013;75(1):68-72

47. Pertschuk LP, Masood S, Simone J, Feldman JG, Fruchter RG, Axiotis CA, et al. Estrogen receptor immunocytochemistry in endometrial carcinoma: a prognostic marker for survival. Gynecol Oncol. 1996;63(1):28-33.

48. Mhawech-Fauceglia P, Wang D, Samrao D, Liu S. duPont NC, Pejovic T. Trefoil factor family 3 (TFF3) expression and its interaction with estrogen receptor (ER) in endometrial adenocarcinoma. Gynecol Oncol. 2013;130(1):174-80.

49. Wik E, Raeder MB, Krakstad C, Trovik J, Birkeland E, Hoivik EA, et al. Lack of estrogen receptor-a is associated with epithelial-mesenchymal transition and PI3K alterations in endometrial carcinoma. Clin Cancer Res. 2013;19(5):1094-105.

50. Lindahl B, Ferno M, Gullberg B, Norgren A, Willen R. 5-year survival rate in endometrial carcinoma stage $\mathrm{I}-\mathrm{II}$ related to steroid receptor concentration, degree of differentiation, age and myometrial invasion. Anticancer Res. 1992;12(2):409-12.

51. Chambers JT, MacLusky N, Eisenfield A, Kohorn El, Lawrence R, Schwartz PE. Estrogen and progestin receptor levels as prognosticators for survival in endometrial cancer. Gynecol Oncol. 1988;31(1):65-81.

52. Gates EJ, Hirschfield L, Matthews RP, Yap OW. Body mass index as a prognostic factor in endometrioid adenocarcinoma of the endometrium. J Natl Med Assoc. 2006;98(11):1814-22.

53. Zhang G-Y, Wu L-Y, Li B, Huang M-N, Zhang R, Li X-G. Retrospective analysis of prognostic variables and clinical outcomes in surgically staged intermediate risk endometrial carcinoma. Eur J Obstet Gynecol Reprod Biol. 2013;169(2):309-16.

54. Backe J, Gassel AM, Krebs S, Muller T, Caffier H. Immunohistochemically detected HER-2/neu-expression and prognosis in endometrial carcinoma. Arch Gynecol Obstet. 1997;259(4):189-95.

55. Merritt WM, Kamat AA, Hwang J-Y, Bottsford-Miller J, Lu C, Lin YG, et al. Clinical and biological impact of EphA2 overexpression and angiogenesis in endometrial cancer. Cancer Biol Ther. 2010;10(12):1306-14.

56. Saito S, Ito K, Nagase S, Suzuki T, Akahira J-I, Okamura K, et al. Progesterone receptor isoforms as a prognostic marker in human endometrial carcinoma. Cancer Sci. 2006:97(12):1308-14.

57. Ito K. 14-3-3 in endometrial cancer-a possible prognostic marker in early-stage cancer. Clin Cancer Res. 2005;11(20):7384-91.

58. Salvesen $\mathrm{HB}$, Iversen $\mathrm{OE}$, Akslen LA. Identification of high-risk patients by assessment of nuclear Ki-67 expression in a prospective study of endometrial carcinomas. Clin Cancer Res. 1998;4(11):2779-85.

59. Lenhard M, Heublein S, Kunert-Keil C, Vrekoussis T, Lomba I, Ditsch N, et al. Immunosuppressive Glycodelin A is an independent marker for poor prognosis in endometrial cancer. BMC Cancer. 2013;13:616.

60. Sho T, Hachisuga T, Nguyen TT, Urabe R, Kurita T, Kagami S, et al. Expression of estrogen receptor-a as a prognostic factor in patients with uterine serous carcinoma. Int J Gynecol Cancer. 2014:24(1):102-6.

61. Huvila J, Talve L, Carpen O, Edqvist PH, Ponten F, Grenman S, et al. Progesterone receptor negativity is an independent risk factor for relapse in patients with early stage endometrioid endometrial adenocarcinoma. Gynecol Oncol. 2013;130(3):463-9.

62. Sakaguchi H, Fujimoto J, Hong B, Nakagawa Y, Tamaya T. Drastic decrease of progesterone receptor form $B$ but not $A$ mRNA reflects poor patient prognosis in endometrial cancers. Gynecol Oncol. 2004:93(2):394-9.

63. Steiner E, Eicher O, Sagemuller J, Schmidt M, Pilch H, Tanner B, et al. Multivariate independent prognostic factors in endometrial carcinoma: a clinicopathologic study in 181 patients: 10 years experience at the Department of Obstetrics and Gynecology of the Mainz University. Int J Gynecol Cancer. 2003;13(2):197-203. 
64. Sutton GP, Geisler HE, Stehman FB, Young PC, Kimes TM, Ehrlich CE. Features associated with survival and disease-free survival in early endometrial cancer. Am J Obstet Gynecol. 1989;160(6):1385-91. discussion 1391-1383.

65. Ehrlich CE, Young PC, Stehman FB, Sutton GP, Alford WM. Steroid receptors and clinical outcome in patients with adenocarcinoma of the endometrium. Am J Obstet Gynecol. 1988;158(4):796-807.

66. Togami S, Sasajima Y, Oi T, Ishikawa M, Onda T, Ikeda S-I, et al. Clinicopathological and prognostic impact of human epidermal growth factor receptor type 2 (HER2) and hormone receptor expression in uterine papillary serous carcinoma. Cancer Sci. 2012;103(5):926-32.

67. Mori N, Kyo S, Nakamura M, Hashimoto M, Maida Y, Mizumoto Y, et al. Expression of HER-2 affects patient survival and paclitaxel sensitivity in endometrial cancer. Br J Cancer. 2010;103(6):889-98.

68. Konecny GE, Santos L, Winterhoff B, Hatmal M, Keeney GL, Mariani A, et al. HER2 gene amplification and EGFR expression in a large cohort of surgically staged patients with nonendometrioid (type II) endometrial cancer. Br J Cancer. 2009;100(1):89-95.

69. Odicino FE, Bignotti E, Rossi E, Pasinetti B, Tassi RA, Donzelli C, et al. HER-2/ neu overexpression and amplification in uterine serous papillary carcinoma: comparative analysis of immunohistochemistry, real-time reverse transcription-polymerase chain reaction, and fluorescence in situ hybridization. Int J Gynecol Cancer. 2008;18(1):14-21.

70. Santin AD, Bellone S, Van Stedum S, Bushen W, Palmieri M, Siegel ER, et al. Amplification of c-erbB2 oncogene. Cancer. 2005;104(7):1391-7.

71. Santin AD, Bellone S, Siegel ER, Palmieri M, Thomas M, Cannon MJ, et al. Racial differences in the overexpression of epidermal growth factor type ॥ receptor (HER2/neu): a major prognostic indicator in uterine serous papillary cancer. Am J Obstet Gynecol. 2005;192(3):813-8.

72. Coronado PJ, Vidart JA, Lopez-asenjo JA, Fasero M, Furio-bacete V, Magrina J, et al. P53 overexpression predicts endometrial carcinoma recurrence better than HER-2/neu overexpression. Eur J Obstet Gynecol Reprod Biol. 2001;98(1):103-8.

73. Kohlberger P, Loesch A, Koelbl H, Breitenecker G, Kainz C, Gitsch G. Prognostic value of immunohistochemically detected HER-2/neu oncoprotein in endometrial cancer. Cancer Lett. 1996:98(2):151-5

74. Saffari B, Jones LA, el-Naggar A, Felix JC, George J, Press MF. Amplification and overexpression of HER-2/neu (c-erbB2) in endometrial cancers: correlation with overall survival. Cancer Res. 1995;55(23):5693-8.

75. Peiró G, Mayr D, Hillemanns P, Löhrs U, Diebold J. Analysis of HER-2/neu amplification in endometrial carcinoma by chromogenic in situ hybridization. Correlation with fluorescence in situ hybridization, HER-2/neu, p53 and Ki-67 protein expression, and outcome. Mod Pathol. 2004;17(3):227-87.

76. Cianciulli AM, Guadagni F, Marzano R, Benevolo M, Merola R, Giannarelli D, et al. HER-2/neu oncogene amplification and chromosome 17 aneusomy in endometrial carcinoma: correlation with oncoprotein expression and conventional pathological parameters. J Exp Clin Cancer Res. 2003;22(2):265-71

77. Thomas C, Gustafsson JA. The different roles of ER subtypes in cancer biology and therapy. Nat Rev Cancer. 2011;11(8):597-608.

78. Brack S, Attinger-Toller I, Schade B, Mourlane F, Klupsch K, Woods R, et al. A bispecific HER2-targeting FynomAb with superior antitumor activity and novel mode of action. Mol Cancer Ther. 2014;13(8):2030-9.

79. Xu M, Schwartz P, Rutherford T, Azodi M, Santin A, Silasi D, et al. HER-2/neu receptor gene status in endometrial carcinomas: a tissue microarray study. Histopathology. 2010;56(2):269-73.

80. Rolitsky CD, Theil KS, McGaughy VR, Copeland LJ, Niemann TH. HER-2/neu amplification and overexpression in endometrial carcinoma. Int J Gynecol Pathol. 1999;18(2):138-43.

81. Santin AD, Bellone S, Van Stedum S, Bushen W, De Las Casas LE, Korourian $\mathrm{S}$, et al. Determination of HER2/neu status in uterine serous papillary carcinoma: comparative analysis of immunohistochemistry and fluorescence in situ hybridization. Gynecol Oncol. 2005;98(1):24-30.

82. Slomovitz BM, Broaddus RR, Burke TW, Sneige N, Soliman PT, Wu W, et al. Her-2/neu overexpression and amplification in uterine papillary serous carcinoma. J Clin Oncol. 2004;22(15):3126-32.

83. Halperin R, Zehavi S, Habler L, Hadas E, Bukovsky I, Schneider D. Comparative immunohistochemical study of endometrioid and serous papillary carcinoma of endometrium. Eur J Gynaecol Oncol. 2001;22(2):122-6

84. Hayes DF, Isaacs C, Stearns V. Prognostic factors in breast cancer: current and new predictors of metastasis. J Mammary Gland Biol Neoplasia. 2001;6(4):375-92.

85. Liu R, Dong JT, Chen C. Role of KLF5 in hormonal signaling and breast cancer development. Vitam Horm. 2013;93:213-25.

86. Ito K, Utsunomiya $\mathrm{H}$, Yaegashi $\mathrm{N}$, Sasano $\mathrm{H}$. Biological roles of estrogen and progesterone in human endometrial carcinoma-new developments in potential endocrine therapy for endometrial cancer. Endocr J. 2007;54(5):667-79

87. Baylin SB, Herman JG. DNA hypermethylation in tumorigenesis: epigenetics joins genetics. Trends Genet. 2000;16(4):168-74.

88. Grady D, Gebretsadik T, Kerlikowske K, Ernster V, Petitti D. Hormone replacement therapy and endometrial cancer risk: a meta-analysis. Obstet Gynecol. 1995;85(2):304-13.

89. Bokhman JV. Two pathogenetic types of endometrial carcinoma. Gynecol Oncol. 1983;15(1):10-7.

90. Mueller SO, Korach KS. Estrogen receptors and endocrine diseases: lessons from estrogen receptor knockout mice. Curr Opin Pharmacol. 2001;1(6):613-9.

91. Yang P, Kriatchko A, Roy SK. Expression of ER-alpha and ER-beta in the hamster ovary: differential regulation by gonadotropins and ovarian steroid hormones. Endocrinology. 2002;143(6):2385-98.

92. Utsunomiya H, Suzuki T, Harada N, Ito K, Matsuzaki S, Konno R, et al. Analysis of estrogen receptor alpha and beta in endometrial carcinomas: correlation with ER beta and clinicopathologic findings in 45 cases. Int J Gynecol Pathol. 2000;19(4):335-41.

93. Sakaguchi H, Fujimoto J, Aoki I, Toyoki H, Khatun S, Tamaya T. Expression of oestrogen receptor alpha and beta in uterine endometrial and ovarian cancers. Eur J Cancer. 2002;38 Suppl 6:S74-5.

94. Jongen VH, Thijssen JH, Hollema H, Donker GH, Santema JG, Van der Zee AG, et al. Is aromatase cytochrome P450 involved in the pathogenesis of endometrioid endometrial cancer? Int J Gynecol Cancer. 2005;15(3):529-36

95. Kastner P, Krust A, Turcotte B, Stropp U, Tora L, Gronemeyer H, et al. Two distinct estrogen-regulated promoters generate transcripts encoding the two functionally different human progesterone receptor forms $\mathrm{A}$ and $\mathrm{B}$. EMBO J. 1990;9(5):1603-14.

96. Giangrande PH, Kimbrel EA, Edwards DP, McDonnell DP. The opposing transcriptional activities of the two isoforms of the human progesterone receptor are due to differential cofactor binding. Mol Cell Biol. 2000;20(9):3102-15.

97. Horwitz KB. The molecular biology of RU486. Is there a role for antiprogestins in the treatment of breast cancer? Endocr Rev. 1992;13(2):146-63.

98. Lessey BA, Alexander PS, Horwitz KB. The subunit structure of human breast cancer progesterone receptors: characterization by chromatography and photoaffinity labeling. Endocrinology. 1983;112(4):1267-74.

99. Gronemeyer H, Meyer ME, Bocquel MT, Kastner P, Turcotte B, Chambon P. Progestin receptors: isoforms and antihormone action. J Steroid Biochem Mol Biol. 1991;40(1-3):271-8.

100. Mulac-Jericevic B, Lydon JP, DeMayo FJ, Conneely OM. Defective mammary gland morphogenesis in mice lacking the progesterone receptor B isoform. Proc Natl Acad Sci U S A. 2003;100(17):9744-9.

101. Mulac-Jericevic B, Mullinax RA, DeMayo FJ, Lydon JP, Conneely OM. Subgroup of reproductive functions of progesterone mediated by progesterone receptor-B isoform. Science. 2000;289(5485):1751-4.

102. Borg A, Linell F, Idvall I, Johansson S, Sigurdsson H, Ferno M, et al. HER2/neu amplification and comedo type breast carcinoma. Lancet. 1989;1(8649):1268-9.

103. Kuzhan A, Adli M, Eryigit Alkis H, Caglayan D. Hormone receptor and HER2 status in patients with breast cancer by races in southeastern Turkey. J BUON. 2013;18(3):619-22 